\author{
„LAJKI" I „HEJTY”, CZYLI KILKA SŁÓW O SOCJOLEKCIE \\ POLSKICH I ROSYJSKICH UŻYTKOWNIKÓW INTERNETU
}

\author{
‘LIKES’ AND ‘HATES’, I.E. A FEW WORDS ON THE SOCIOLECT \\ OF POLISH AND RUSSIAN INTERNET USERS
}

\title{
KATARZYNA KULIGOWSKA
}

\begin{abstract}
The author presents several psycho- and sociolinguistic phenomena connected with Internet use. An analysis of the sociolect of Polish and Russian Internet users allows the author to establish the main kinds of human activity in the Internet and what the impact that using the Internet has on the individual.
\end{abstract}

Katarzyna Kuligowska, Uniwersytet im. Adama Mickiewicza w Poznaniu, Poznań - Polska, katarzyna.kuligowska@amu.edu.pl

Niezwykle dynamiczne zmiany dokonujące się w świecie w ostatnich dziesięcioleciach, będące konsekwencją ogromnego postępu technicznego i rozwoju nowych technologii oraz fenomenu, jakim jest internet, mają niebywały wpływ na życie całych społeczności, a co za tym idzie - na sposób komunikowania się ich członków i zarazem na zmiany zachodzące w języ$\mathrm{ku}$, którym owe społeczności się posługują.

Sposób komunikowania się za pomocą komputerów, przy użyciu internetu, stał się już przedmiotem wielu badań i analiz naukowych. W literaturze anglojęzycznej dyscyplina ta określana jest jako computer-mediated communication (CMC). Autorzy polskich prac na ten temat używają określeń typu komunikacja elektroniczna, komunikacja medialna lub komunikacja za pośrednictwem sieci komputerowych ${ }^{1}$. Jak podkreśla Jan Grzenia,

Podstawowym celem tej dyscypliny powinno być badanie komputerów jako narzędzi komunikacji [...]. Równie ważne wydaje się badanie wpływu komputerów na możliwości komunikatywne człowieka, a w konsekwencji także ich wpływu na język².

Wojciech Gustowski zauważa, że „w połączeniu z coraz nowszymi technologiami i możliwościami, jakie internet oferuje, mamy do czynienia

1 Vide J. G r z e n i a, Komunikacja jezykowa w Internecie, Warszawa 2006, s. 13; W. G u s t o w s k i, Komunikacja w mediach społecznościowych, Gdynia 2012, s. 31.

2 J. Gr z e n i a, op. cit., s. 14. 
z sytuacją, w której zaczyna on zastępować wszystkie inne sposoby komunikacji" ${ }^{3}$.

Niniejszy artykuł jest próbą prezentacji kilku zjawisk o charakterze psycho- i socjolingwistycznym, wynikających z upowszechnienia się komunikacji elektronicznej, a związanych, posługując się słowami badaczy, z „komunikacją społeczną jednostki $\mathrm{w}$ wirtualnym świecie" $\mathrm{z}$ jednej strony $\mathrm{i}$,"skutkami korzystania z internetu dla życia jednostki w świecie realnym" z drugiej strony ${ }^{4}$. Wspomniane zjawiska zostaną zaprezentowane na polskim i rosyjskim materiale leksykalnym, będącym wycinkiem specyficznego socjolektu osób posługujących się internetem i korzystających z niego w celu komunikowania się z innymi jego użytkownikami. Leksyka, która posłużyła do badań, została zaczerpnięta $\mathrm{z}$ kilkunastu wydań polskich tygodników o charakterze społeczno-politycznym („Newsweek", „Polityka”) z okresu 2013-2015 oraz podobnej liczby internetowych wydań czasopism rosyjskich („Взгляд”, „Огонек”) z okresu 2007-2015. Źródłem żargonowych wyrażeń było także Nowe słownictwo polskie. Materiaty z prasy lat 2001$2005^{5}$, specjalne wydanie tygodnika „Polityka” pt. Ja My Oní, jak również publikacje naukowe dotyczące komunikacji medialnej, wskazane w bibliografii. Ogółem zebranych i przeanalizowanych zostało około 170 polskich i około 180 rosyjskich jednostek leksykalnych, w przeważającej większości stanowiących pojedyncze leksemy.

Internet stał się nieodłącznym elementem życia tak jednostki, jak i zbiorowości. „Nowa technologia na stałe weszła w życie społeczne, ułatwiając i przyśpieszając komunikację (e-mail), stając się źródłem informacji (strony WWW), ułatwiając przesyłanie programów, plików (FTP), objęła sferę tzw. e-biznesu $[\ldots]^{\prime \prime} 7$. Liczba osób wykorzystujących internet w różnych celach, zawodowych i prywatnych, rośnie lawinowo z roku na rok. Badania z lat 2003-2004 wskazywały, że w Polsce jest ok. 8-9 mln internautów ${ }^{8}$, według danych zaś dla pierwszego kwartału 2015 roku wynik ten zwiększył się do niemal $30 \mathrm{mln} .{ }^{9}$ Podobne tendencje występują $\mathrm{w}$ Rosji, gdzie liczba inter-

${ }^{3}$ W. G u s t o w s k i, op. cit., s. 30.

${ }^{4}$ B. S z m i g i e l s k a, Rola internetu w biegu życia ludzkiego, [w:] Całe życie w Sieci, pod red. B. Szmigielskiej, Kraków 2008, s. 8.

${ }^{5}$ Nowe stownictwo polskie. Materiaty z prasy lat 2001-2005, pod red. T. Smółkowej, cz. I-V, Kraków 2010-2014.

6 Ja My Oni. Poradnik Psychologiczny „Polityki”, t. 16: Co komputer zrobit nam z głowa, „Polityka” 2014, nr 9.

7 B. P r z y w a r a, Człowiek w sieci. Socjologiczne studium przypadku, [w:] Jednostka - grupa - cybersieć. Psychologiczne, społeczno-kulturowe i edukacyjne aspekty społeczeństwa informacyjnego, pod red. M. Radochońskiego i B. Przywary, Rzeszów 2004, s. 143.

${ }^{8}$ J. G r z e n i a, op. cit., s. 46.

9 Źródło elektroniczne: http://www.egospodarka.pl/124395,Internet-w-Polsce-I-III2015,1,12,1.html (18.08.2015). 
nautów w ciągu ostatniego roku wzrosła o 5\% i na początku 2015 roku wyniosła $82 \mathrm{mln} \cdot{ }^{10}$

Leksemy opisujące funkcjonowanie jednostki ludzkiej w wirtualnym świecie tworzą $\mathrm{w}$ badanym materiale najobszerniejsze pole semantyczne. Dotyczą one wszystkich aspektów internetowej aktywności człowieka. Są wśród nich ogólne wyrażenia wskazujące na sposoby komunikowania się i działania użytkowników internetu, np. cyberświat, cyberprzestrzeń, cyberslacking (okazj. 'włóczenie się po internecie'); кибер-пространство, киберспейс, чат, фрлэшмоб ('заранее спланированная массовая акция, в которой большая группа людей появляется в общественном месте, выполняет заранее оговоренные действия и затем расходится'), смартмоб, сёрфинг, nazwy portali i źródeł informacji, np. blogosfera, czatroom, cybercmentarz, darknet, seksportal, wall; интернет-кафе, онлайн-архив, онлайн-библиотека, „стена"11, сайm, Видеохостинг ("сайт, позволяющий загружать и просматривать видео в браузере'), określenia związane z publikowaną treścią, np. lolkontent/lolcontent ('publikowane $\mathrm{w}$ internecie treści o charakterze rozrywkowym, często wyśmiewające osoby, zachowania lub cechy'), mem ('umieszczana $\mathrm{w}$ internecie porcja informacji w postaci krótkiego filmu, zdjęcia, często z zabawnym komentarzem'), snap ('zdjęcie wysyłane przez internet za pośrednictwem serwisu Snapchat, które jest kasowane po ok. 10 sekundach od wyświetlenia'), koment, fota; публикуемый контент, перепосты, микроблог, интернет-мем, твит, ретвит, хештег/хэштег ('метка'), oraz nazwy użytkowników internetu i jego zasobów, np. cyberrandkowicz, randkonautka, surfer, vloger ('osoba publikujaca w internecie nagrane przez siebie krótkie filmy video', video + bloger), netowicz, "ceWEBryci” (okazj. 'znane postaci sieci', ang. web + celebrity); интернет-пользователь, юзер, чатланин, геимер.

Odnotowane zostały także określenia związane z prowadzeniem działalności komercyjnej $\mathrm{w}$ przestrzeni internetowej, np. e-zakupy, e-konsument, e-sklep, showrooming ("wizyty $\mathrm{w}$ tradycyjnych sklepach, służące temu, by obejrzeć z bliska sprzęt, który chce się kupić w internecie'); онлайн-бренды, онлайн-торговля, интернет-маркетинг, интернет-рынки, jak i terminy socjologiczne i społeczno-polityczne, cyberkolonizacja, crowdfunding ('forma zbierania kapitału od użytkowników internetu na przedsięwzięcia społeczne'), pokolenie tzw. sieciaków, e-maskacja, e-administracja, dewirtualizacja, cyberprzyszłość, webringi ('forma zrzeszania ludzi posiadających strony www, pierścienie webowe'); интернет-интеграция, интернет-сообщество, кибер-эпоха, интернет-инициатив, интернет-голосование. Znaczące pod względem ilości miejsce zajmują nazwy związane ze środkami masowego przekazu i reklamą,

\footnotetext{
10 Źródło elektroniczne: http://news.softodrom.ru/ap/b21812.shtml (18.08.2015).

$11 \mathrm{~W}$ cudzysłowie prezentowane są wyrazy należące do leksyki okazjonalnej.
} 
np. informacyjna e-powódź, streaming ('technika dostarczania informacji multimedialnej na życzenie najczęściej poprzez internet'), advertainment ('przekaz reklamowy w rozrywkowej formie'); интернет-СМИ, интернет-утка ('непроверенная или преднамеренно ложная информация, опубликованная в интернете'), интернет-трансляиия, интернет-опрос, соимедия, оффлайновая реклама. Odrębną grupę tematyczną stanowią nazwy urządzeń oraz terminy z zakresu technologii informatycznych, np. smartfon, tablet, aplikacja, iPhone; дата-центр, вай-фай, IT-индустрия, IР-телефония, зетабайт ('триллион гигабайтов'), Android-yстройствo. Tego typu leksemy J. Grzenia zalicza do słownictwa komputerowego, wyraźnie oddzielając je od jednostek należących do leksyki internetowej ${ }^{12}$.

Z aktywnością jednostki i instytucji $w$ internecie wiąże się problem zaufania i jego nadużywania przez niektórych użytkowników globalnej sieci.

Strategia ograniczonego zaufania w środowisku internetowym znajduje [...] specyficzne uzasadnienie. W Sieci nierzadko mamy do czynienia z osobami, które nie podają swoich prawdziwych danych bądź dają niewiele wskazówek umożliwiających celne odczytanie ich tożsamości¹3.

W badanym socjolekcie występują określenia takie, jak fejk ('fałszywy komunikat nadawany z konta osoby podszywającej się pod kogoś innego' lub 'osoba podszywająca się pod innego użytkownika sieci'), fejkowanie. $\mathrm{Na}$ brak zaufania bez wątpienia wpływ mają także przypadki nadużycia bądź łamania prawa. Przestępczość wirtualna przybiera coraz to nowe formy i coraz większe rozmiary. Znajduje to potwierdzenie $w$ materiale językowym, w którym liczne są wyrażenia opisujące typy przestępców, stosowane przez nich środki i rodzaje dokonywanych przez nich czynów, np. cracker, haker, cyberagresor, cyberbullying, cyberprzemoc, cyberatak, trojan ('rodzaj złośliwego oprogramowania, które, podszywając się pod przydatne lub ciekawe dla użytkownika aplikacje, dodatkowo implementuje niepożądane, ukryte przed użytkownikiem różne funkcje'), ransomware ('oprogramowanie, które po otworzeniu załącznika szyfruje pliki na komputerze'), phishing ('rodzaj oszustwa internetowego, w którym przestepca podszywa się pod inną osobę lub instytucję $\mathrm{w}$ celu wyłudzenia określonych informacji, np. danych logowania lub szczegółów karty kredytowej'); интернет-вандал, интернет-мотенник, кибер-группировка, кибер-терроризм, кейлоггер ('программное обеспечение, регистрирующее различные действия пользователя компьютера, клавиатурный шпион'), кибер-щпионаж, спам-атака, „кибер-джихад”.

12 J. G r z e n i a, op. cit., s. 127.

${ }^{13} \mathrm{~K}$. S t a c h u r a, Zaufanie i nieufność w Internecie. Analiza wybranych determinantów kapitału społecznego, [w:] Com.unikowanie w zmieniającym się społeczeństwie, pod red. M. Niezgody, M. Świątkiewicz-Mośny, A. Wagner, Kraków 2010, s. 142. 
Innym negatywnym zjawiskiem związanym $\mathrm{z}$ funkcjonowaniem $\mathrm{w}$ wirtualnym świecie jest agresja przejawiająca się $\mathrm{w}$ otwartym wyrażaniu niechęci lub wręcz nienawiści wobec pojedynczych internautów lub całych grup ludzi o charakterze politycznym, religijnym czy mniejszościowym. Zdaniem Pawła Majchrzaka i Niny Ogińskiej-Bulik „zjawisko to jest często odnotowywane jako potencjalne zagrożenie dla użytkowników wszystkich form komunikacji internetowej"14. Jego ilustracją na płaszczyźnie językowej są określenia typu hejting, hejterstwo, hejter, flejm ('szybko nasilający się spór internetowy'), 'хейm-спич', хейт-группы, тролинг ('злонамеренное вмешательство в сетевую коммуникацию, выражающееся в нагнетании участником общения гнева, конфликта путем скрытого или явного задирания, принижения, оскорбления другого участника или участников, зачастую с нарушением правил сетевой коммуникации').

$\mathrm{W}$ celu zapobiegania tym negatywnym zjawiskom $\mathrm{w}$ sieci szeroko dyskutuje się o skutecznych sposobach obrony użytkowników internetu. Na łamach prasy pojawiają się więc takie określenia jak cyberarmia, cyberbezpieczeństwo; кибер-защита, киберполиция, кибер-жертва, медиабезопасность.

Jednym z ważniejszych fragmentów przestrzeni wirtualnej stały się w ostatnich kilkunastu latach tzw. serwisy społecznościowe, które pozwalają na tworzenie własnego profilu, prezentowanie własnych poglądów, przekazywanie informacji o sobie oraz komunikowanie się $\mathrm{z}$ innymi. Jako niezwykle ważną funkcję tego typu zjawisk badacze wymieniają również zaspokojenie potrzeby przynależności do określonej grupy społecznej15. W Polsce pierwszym takim portalem była „Nasza klasa”, której liczba użytkowników w czerwcu 2008 roku, według danych opublikowanych w pracy Uzależnienie od internetu, wynosiła ponad 11 milionów ${ }^{16}$. W Rosji podobne funkcje spełniają portale „ВКонтакте” і „Одноклассники” z dziesiątkami milionów uczestników, a w ostatnich latach na całym świecie rekordy popularności bije Facebook (fejs, fejsbuk), w którym swój profil założyło już kilkaset milionów osób ${ }^{17}$. Przyłączanie się do społeczności sieciowych $\mathrm{w}$ dużym stopniu wynika $\mathrm{z}$ chęci autoprezentacji i potrzeby akceptacji, bowiem

prezentując swój „profil” użytkownik dokonuje niejako promocji własnej osoby pod wieloma ważnymi dla niego względami, pokazując zainteresowania i hobby, osiągnięcia oraz krąg swoich bliższych i dalszych znajomych [...] $]^{18}$.

14 P. M a j c h r z a k, N. O g i ń s k a - B u l i k, Uzależnienie od internetu, Łódź 2010, s. 18.

15 Tamże, s. 22.

16 Tamże.

17 Ł. K a p r a $1 \mathrm{~s} \mathrm{k} \mathrm{a,} \mathrm{O} \mathrm{komunikacyjnych} \mathrm{i} \mathrm{integracyjnych} \mathrm{funkcjach} \mathrm{serwisów} \mathrm{społeczno-}$ ściowych, [w:] Com.unikowanie w zmieniającym się..., op. cit., s. 266.

18 Tamże, s. 264. 
Słownictwo opisujące funkcjonowanie jednostki na portalach społecznościowych można podzielić na określenia dotyczące autoprezentacji użytkowników, np. e-wizerunek, e-maska; нuк, abamap, określenia związane z aktywnością użytkowników, m. in. polubienia, szery ('udostępnienia'), sexting / seksting ('wysyłanie zdjęć lub filmów o treści erotycznej'), ıайк ('одобрение'), нравится ('одобрение'), дизлайк, просмотры, oraz nazwy osób, np. fejsbukowicz, twitterowiec, follower ('osoba obserwująca czyjś profil na portalu społecznościowym'); вконтактовские школьники, инстаграммер, твиттерянин. Szczególnie popularne stało się wyrażenie lajk (ros. ^aũk), oznaczające akceptację lub wyrażenie aprobaty, podziwu dla prezentowanej przez użytkowników portalu treści, zdjęcia, lub innej zawartości komunikatu. W zebranym materiale znajdują sie wyrażenia typu (za)lajkować, pozyskiwanie lajków, nabijać lajki, zbijanie lajków, lajker; накрутка лайков, набирать лайки, лайк-машина, лайкнуть, (по)ставить лайк.

Obserwacja portali społecznościowych pozwala wnioskować, że ich członkowie najczęściej i najchętniej dzielą się z innymi swoimi zdjęciami. $\mathrm{Z}$ faktem tym wiąże się kolejny językowy fenomen, czyli szereg określeń dotyczących umieszczanych na profilu użytkownika fotografii autoportrettowych, np. sweet fotka (sweet focia), wulg. samojebka, selfie; ros. селфи, съемка-селфи, „себяшка”, филешка, дакфейс ("характерное выражение лица, при котором губы вытягиваются вперед'), peлфи (od ang. relationship i selfie, 'фотография с любимым человеком'), лифтлук ('фотография, сделанная самостоятельно у зеркала в лифте'). Słowo selfie zostało uznane przez twórców słowników Oxford University Press za słowo roku 2013'19. Wykonywanie tego typu zdjęć stało sie niezwykle łatwe dzięki upowszechnieniu się aparatów cyfrowych, tabletów oraz telefonów komórkowych z wbudowanym aparatem o wysokiej rozdzielczości (iPhone; смартфон, камерафон, Android-ycmpoũcmbo), a także specjalnych ręcznych statywów, znanych jako: wysiegnik do selfie, kijek do selfie; селфи-монопод, итатив для селфи, селфи-naлka, lub coraz to nowszych wynalazków, jak np. „селфи-myфлu”.

Uczestnicy portali społecznościowych prześcigają się $\mathrm{W}$ prezentacji selfie, starając się wykonać jak najciekawsze ujęcia, co niekiedy prowadzi do ryzykownych zachowań. "Селфи - уже не просто странное хобби, а вопрос жизни и смерти." - napisał rosyjski dziennikarz Leonid Mikulak w gazecie „Московский комсомолец" 20. W związku z tragicznymi wypadkami, które miały miejsce przy wykonywaniu tych popularnych auto-

19 Źródło elektroniczne: http://www.spidersweb.pl/2013/11/selfie-slowem-roku.html (10.08.2015).

20 „Московский комсомолец” 8 июля 2015, № 26853, [w:] źródło elektroniczne: http://www.mk.ru/social/2015/07/07/ pamyatku-mvd-o-bezopasnykh-selfi-razmestilina-meste-gibeli-moskvichki.html (16.08.2015). 
portretów, rosyjskie Ministerstwo Spraw Wewnętrznych opublikowało poradnik pt. Безопасное селфри ${ }^{21}$.

Czas spędzany $\mathrm{w}$ wirtualnym świecie nie pozostaje bez wpływu na funkcjonowanie człowieka $\mathrm{w}$ realnym życiu. Często zdarza się, że jest to wpływ negatywny i destrukcyjny. Naukowcy niejednokrotnie już podejmowali temat nadmiernego użytkowania komputera i internetu czy wręcz internetowego uzależnienia, które porównywane jest do innego typu nałogów, np. alkoholizmu czy uzależnienia od hazardu22. Psychologowie wyróżniają za amerykańską badaczką Kimberly Young pięć typów uzależnień związanych z użytkowaniem komputera i internetu, do których przypisać można obrazujące je jednostki językowe:

- erotomania internetowa - uzależnienie od filmów i zdjęć o charakterze pornograficznym, uczestniczenie $\mathrm{w}$ czatach o tematyce seksualnej (pornonauci, cyberseks, cyberek ('seks wirtualny'), секстинг),

- socjomania internetowa - uzależnienie od portali społecznościowych i komunikacji internetowej (czatoholik, czatmaniaczka, селфимания, одержимость селфи, селфи-расстройство, селфит ('патологическая зависимость от селфи'), e-mail апноэ ('состояние, в котором человеку не хватает электронических писем и новых сообщений в соцсетях'),

- uzależnienie od sieci internetowej, $m$. in. sieciowych gier hazardowych, zakupów on-line itp. (e-zakupoholik, интернет-казино),

- przeciążenie informacyjne czyli przymus pobierania informacji (infoholik, informacyjna e-powódź),

- uzależnienie od gier komputerowych (геймоголик, игроман) ${ }^{23}$.

Do przedstawionych typów uzależnienień można dołączyć nadmierne używanie telefonów komórkowych, umożliwiających korzystanie z internetu, co również znalazło już swoje odbicie w systemie leksykalnym zarówno języka polskiego, jak i rosyjskiego, por. komórkoholizm, fonoholizm, номофобия ('боязнь оказаться вне зоны доступа мобильной связи').

Analizowany materiał leksykalny dotyczący problematycznego użytkowania internetu i komputerów zawiera ponadto ogólne nazwy tego zjawiska, np. sieciouzależnienie, siecioholizm, cybernałóg, efekt Hikikomori ('uzależnienie od internetu, którego ofiara kontaktuje sie ze światem zewnętrznym jedynie za pomоса sieci'); интернетомания, интернет-наркомания, интернет-аддикиия, интернет-зависимость, онлайн-зависимость, oraz nazwy osób dotkniętych owym problemem, np. internetoholik, cybermaniak, appleholik; интернет-зависимый, „интернет-наркоман”.

21 Źródło elektroniczne: https://mvd.ru/safety_selfie (16.08.2015).

22 Vide P. M a j c h r z a k, N. O g i ń s k a - B u k, op. cit.

${ }^{23} \mathrm{M}$. K o s z e m b a r - W i k l i k, Advertainment $i$ marketing wirusowy - nowe formy komunikacji z odbiorca, [w:] Com.unikowanie w zmieniajacym się..., op. cit., s. 322-323. 
Analiza strukturalna leksemów z socjolektu internautów pozwoliła wyodrębnić kilka grup wyrazów: zapożyczenia, derywaty słowotwórcze, złożenia i neosemantyzmy.

Wyrazy zapożyczone stanowią w polskim zebranym materiale ok. 35\%. Niemal bez wyjatku ich źródłem jest język angielski, np. wall, showrooming, follower, keylogger, crowdfunding. Część zapożyczeń zapisywana jest w wersji spolszczonej, np. lajk(i) (ang. like), fejk(i) (ang. fake), hejter (ang. hater), fejm (ang. fame), fejsbuk (ang. Facebook), niektóre zaś występują w dwóch wersjach, np. czatroom / chatroom, ha sztag / hashtag, seksting / sexting. Jedynym zapożyczeniem z języka innego niż angielski jest nazwa hikikomori pochodzenia japońskiego (jap. hiku - 'wycofywać się', komoru - 'być w zamku i chronić się́). Rosyjski materiał leksykalny zawiera ok. 18\% wyrazów zapożyczonych z języka angielskiego, które zgodnie z językową tradycją zapisywane są w wersji fonetycznej, np. фрлэшмоб (ang. flashmob), троллинг (ang. trolling), кейлоггер (ang. keylogger), дизлайк (ang. dislike), мессенджер (ang. messenger), чат (ang. chat), геймер (ang. gamer), контент (ang. content).

Wyrazy zapożyczone $w$ obu językach w szybkim tempie stają się podstawami słowotwórczymi nowych derywatów, głównie przymiotników i czasowników, np. fejsbukowy/facebookowy, crowdfundingowy, hejterski, twitterowy, rozemotikowany, googlować/guglować, linkować, szerować ('udostepniać', od ang. to share 'dzielić się), hejtować, lolować ('wyśmiewać', od ang. lol 'laughing out loud'), zdefriendować ('wykluczyć z grona znajomych na portalu społecznościowym'); цатовый, контентный (w wyrażeniu контентное пиратство), офрляайновый, браузерный, фейсбучный, лайкнуть, постить, чатиться, тэгить, твитить, Rzadziej tworzone są rzeczowniki o znaczeniu osoby lub procesu czy stanu, np. czatownik, czatowniczka, twitterowiec, hakerstwo, banowanie, hejterstwo, lolowanie; твитерянин, чатланин, селфит. Derywaty powstałe $\mathrm{w}$ oparciu o rodzime tematy wystepują $\mathrm{w}$ zebranym materiale w niewielkiej liczbie, np. sieciaki ('pokolenie osób w wieku szkolnym i studenckim, spędzających większość czasu $\mathrm{w}$ internecie'), sieciouzależnienie, przedsieciowy (w wyrażeniu pokolenie przedsieciowe).

W grupie złożeń - tak polskich, jak i rosyjskich - przeważają wyrazy zbudowane z dwóch komponentów o charakterze internacjonalnym lub internacjonalnego komponentu prepozytywnego i tematu rodzimego. Wśród wyrazów polskich w prepozycji najczęściej występuje cząstka cyber- oraz e-, np. cyberdetoks, cybermaniak, cyberpartner, cyberprzestępczość, cyberfobia, e-zakupy, e-wizerunek, e-sklep, e-handel, e-firma. W złożeniach rosyjskich najczęściej wyzyskiwane są komponenty интернет-, кибер-, онлайн-, nр. интернет-холдинг, интернет-ресурс, интернет-трансляция, киберпреступник, кибер-эпоха, кибератака / кибер-атака, онлайн-игры, онлайн-зависимость, онлайн-магазин. Inny typ złożeń występujący $\mathrm{w}$ badanym materiale stanowią kompozyty „z sufiksoidami typu -holik (internetoholik, czatoholik), -holizm (siecioholizm, 
fonoholizm), -fob (globofob), -nauta (randkonauta, pornonauta); -голик (сетеголик), -голизм (сетеголизм), -мания (селфимания), -фобия (номофобия). W је̨zyku rosyjskim ponadto dość swobodnie tworzą się złożenia z komponentem селфи-, nр. селфи-палка, свемка-селфи, селфи-расстройство.

Neosemantyzmy stanowią w badanym materiale znikomą część. Za przykład leksemów powstałych na bazie istniejących w systemie językowym wyrazów można uznać wyrazy: polubienie ('wyrażenie aprobaty, sympatii do materiałów opublikowanych na stronach internetowych; lajk'), стена ('странища, профиль пользователя социальной сети').

Analiza wycinka leksyki używanej przez polskich i rosyjskich użytkowników internetu, wzbogacanej głównie poprzez zapożyczenia i złożenia, pozwoliła na wskazanie najważniejszych zjawisk dotyczących współczesnego człowieka, który funkcjonuje w dwóch równoległych światach - realnym i wirtualnym. Rzeczywistość internetowa to miejsce, w którym jednostka prowadzi nie tylko działalność zawodową, społeczną czy polityczną. Jest to przestrzeń pełniąca również funkcje ludyczne, wykorzystywana do komunikowania się z innymi, nawiązywania i utrzymywania kontaktów towarzyskich. Te rodzaje aktywności pozwalają często na zaspokojenie potrzeby akceptacji i autoprezentacji. Jednakże przeniesienie wielu aspektów życia do cyberprzestrzeni niesie ze sobą różnego rodzaju zagrożenia, jak choćby wzrost wirtualnej przestępczości czy uzależnienie od sieci internetowej.

\section{Bibliografia}

Całe życie $w$ sieci, pod red. B. Szmigielskiej, Wydaw. Uniwersytetu Jagiellońskiego Kraków 2008.

Com.unikowanie w zmieniającym się społeczeństwie, pod red. M. Niezgody, M. Świątkiewicz-Mośny, A. Wagner, Zakład Wydawniczy NOMOS, Kraków 2010

G r z e n i a J., Komunikacja jezzykowa w internecie, Wydaw. Naukowe PWN, Warszawa 2006.

G u s t o w s k i W., Komunikacja w mediach społecznościowych, Novae Res, Gdynia 2012.

Ja My Oni. Poradnik Psychologiczny „Polityki”, t. 16: Co komputer zrobił nam z głowa, „Polityka" 2014, nr 9.

Jednostka - grupa - cybersieć. Psychologiczne, społeczno-kulturowe i edukacyjne aspekty społeczeństwa informacyjnego, pod red. M. Radochońskiego i B. Przywary, Wydaw. Wyższej Szkoły Informatyki i Zarządzania, Rzeszów 2004.

$\mathrm{K}$ a p r a $1 \mathrm{~s}$ k a Ł., O komunikacyjnych i integracyjnych funkcjach serwisów spotecznościowych, [w:] Com.unikowanie w zmieniajacym się..., op. cit., s. 266.

K o s z e m b a r - W i k li k M., Advertainment i marketing wirusowy - nowe formy komunikacji z odbiorca, [w:] Com.unikowanie w zmieniajacym się..., op. cit., s. 322-323. 
M a j c h r z a k P., O g i ń s k a - B u 1 i k P., Uzależnienie od internetu, Wydaw. Akademii Humanistyczno-Ekonomicznej w Łodzi, Łódź 2010.

„Московский комсомолец” 8 июля 2015, № 26853, [w:] źródło elektroniczne: http:// www.mk. ru/social/2015/07/07/pamyatku-mvd-o-bezopasnykh-selfi-razmestili-na-meste-gibelimoskvichki.html (16.08.2015).

Nowe stownictwo polskie. Materiaty z prasy lat 2001-2005, pod red. T. Smółkowej, cz. I-V, Kraków 2010-2014.

P r z y w a r a B., Człowiek w sieci. Socjologiczne studium przypadku, [w:] Jednostka - grupa - cybersieć..., op. cit.

$\mathrm{S} \mathrm{t}$ a c h u r a K., Zaufanie i nieufność w Internecie. Analiza wybranych determinantów kapitatu społecznego, [w:] Com.unikowanie w zmieniajacym się..., op. cit., s. 142.

$\mathrm{S}$ z m i g i e $1 \mathrm{~s} \mathrm{k} \mathrm{a} \mathrm{B.,} \mathrm{Rola} \mathrm{internetu} \mathrm{w} \mathrm{biegu} \mathrm{życia} \mathrm{ludzkiego,} \mathrm{[w:]} \mathrm{Całe} \mathrm{życie} \mathrm{w} \mathrm{Sieci,} \mathrm{pod}$ red. B. Szmigielskiej, Kraków 2008.

Źródło elektroniczne: http://news.softodrom.ru/ap/b21812.shtml (18.08.2015).

Źródło elektroniczne: http://www.egospodarka.pl/124395,Internet-w-Polsce-I-III-2015,1, 12,1.html (18.08.2015). 